\title{
TRANSATLANTIC DOUBLES: INTERTEXTUAL AGEING IN THE EARLY FICTION OF EDGAR ALLAN POE AND EDWARD BULWER-LYTTON ${ }^{1}$
}

\author{
Marta Miquel-Baldellou \\ Email: mmiquel@dal.udl.cat
}

\begin{abstract}
As a literary critic, Edgar Allan Poe reviewed the writings of the Victorian man of letters Edward Bulwer-Lytton on at least four occasions in the span of six years, from 1835 to 1841 . Even if both authors came from significantly different backgrounds, as Poe was of humble origins and Bulwer-Lytton was an English aristocrat, the reversal of fortune, together with their respective personal and parental circumstances, turned them into transatlantic literary doubles, since their fiction often presents considerable intertextual links. Bulwer-Lytton's novella Falkland (1827) and Poe's classical tale "The Assignation" (1832) are rooted in a Byronic myth, depicting a love triangle which particularly echoes both authors' respective parental circumstances. This article aims at providing a comparative analysis of these works, interpreting them from a biographical perspective in order to shed light on both authors' early fiction as well as understanding the role that their respective family background played on their literary creativity and ageing at such an early stage of their career.
\end{abstract}

Keywords: Creativity, biography, early works, transatlantic doubles, illicit relationships, family background, heritage, ageing.

Título en español: Dobles transatlánticos: envejecimiento intertextual en la obra temprana de Edgar Allan Poe y Edward Bulwer-Lytton

Resumen: Como crítico literario, Edgar Allan Poe reseñó las obras del escritor victoriano Edward Bulwer-Lytton en al menos en cuatro ocasiones a lo largo de seis años, desde 1835 a 1841. Pese a que ambos autores procedían de círculos muy diferentes, puesto que Poe nació en el seno de una familia humilde y Bulwer-Lytton era un eminente aristócrata inglés, un golpe del destino, así como sus circunstancias personales y familiares, los convirtieron en dobles literarios transatlánticos, puesto que sus obras a menudo presentan considerables giros intertextuales. La novela corta de Bulwer-Lytton, Falkland (1827), y el relato de corte clásico de Poe, "The Assignation" (1832), se enclavan en un mito byroniano, retratando un triángulo amoroso que presenta múltiples ecos con respecto al parentesco de ambos autores. Este artículo pretende ofrecer un análisis comparativo de ambas obras, interpretándolas desde una perspectiva biográfica con el objetivo de ahondar en las primeras creaciones de ambos autores así como de vislumbrar el importante papel que sus orígenes familiares jugaron en su creatividad literaria y envejecimiento en una etapa tan temprana de su obra.

Palabras clave: creatividad, biografía, primeras obras, dobles transatlánticos, relaciones ilícitas, parentesco, legado, envejecimiento.

Date of reception: 15 June 2011

Date of acceptance: 13 July 2011 


\section{EDGAR ALLAN POE AND EDWARD BULWER-LYTTON AS TRANSATLANTIC DOUBLES}

Edgar Allan Poe's reputation as a writer of dissolute habits mainly arose as a result of the obituary that the editor of his works, Rufus Wilmot Griswold, published in the New York Daily Tribune on October 9 1849, scarcely two days after Poe's death. The 'Ludwig' article, as would ultimately become known, since Griswold signed it using this pseudonym, contains a large amount of biographical details which range from highly accurate information, as is the case with Poe's stay in England during his childhood, to notorious dubious facts such as his improbable trip to Russia at the time John Allan's second wife died. Nonetheless, the most controversial contents of the Ludwig article are precisely related to Griswold's portrayal of Poe's character, as these would significantly contribute to propagating Poe's fame as an irascible and impetuous individual to the extent of considering him a brilliant but an erratic star.

In an attempt to provide an apparently faithful sketch of Poe's personality, Griswold resorted to an alleged likeness established between Poe and Francis Vivian; the latter being a fictional character in Sir Edward Bulwer-Lytton's novel The Caxtons. As the plot unfolds in Bulwer-Lytton's domestic novel, two cousins who are opposed to each other in terms of character, Pisistratus Caxton and Francis Vivian, arise as alter egos, conveying diverse approaches to understanding life and ways of growing into adulthood. If Pisistratus, being the protagonist of Bulwer-Lytton's novel, is considered a responsible and committed individual, his cousin Francis merely indulges in enjoying life and giving free vent to his basest instincts. Given these two opposing characters in Bulwer-Lytton's novel, it is significant to notice that Griswold decided to include in his article a lengthy description of Francis Vivian's depraved personality, taken from Bulwer-Lytton's novel, with the aim to portray Poe's character, thus establishing a link which would remain for years to come:

He [Poe] was in many respects like Francis Vivian in Bulwer's novel of the "Caxtons." "Passion, in him, comprehended many of the worst emotions which militate against human happiness. You could not contradict him, but you raised quick choler; you could not speak of wealth, but his cheek paled with gnawing envy. The astonishing natural advantage of this poor boy - his beauty, his readiness, the daring spirit that breathed around him like a fiery atmosphere - had raised his constitutional self-confidence into an arrogance that turned his very claims to admiration into prejudice against him. Irascible, envious - bad enough, but nor for the worst, for these salient angles were all varnished over with a cold repellent cynicism while his passions vented themselves in sneers. There seemed to him no moral susceptibility; and what was more remarkable in a proud nature, little or nothing of the true point of honor. He had, to a morbid excess, that desire to rise which is vulgarly called ambition, but no wish for the esteem or the love of his species; only the hard wish to succeed - not shine, not serve - succeed, that he might have the right to despise a world which galled his self-conceit”. (Griswold 34)

Griswold's choice to resort to Bulwer-Lytton's depiction of his character Francis Vivian so as to portray Poe does not seem to be random. In addition to the parallelisms Griswold noticed between Poe and Bulwer-Lytton's fictional character in terms of their respective 
personalities, as literary executor of Poe's works and succeeding editor to Graham's Magazine, Griswold must have known about the reviews of Bulwer-Lytton's writings that Poe had published in their journal Graham's Magazine during 1841. Through the course of these reviews, Poe gave evidence of his personal appreciation of the Victorian writer, defending Bulwer-Lytton's fiction and stating he was "a man worthy of all reverence", adding he looked "upon the charges of immoral tendency which ha[d] been so pertinaciously adduced against his fictions, as absurdly little and untenable" (Poe 1841). Poe's willingness to defend Bulwer-Lytton's right to write gothic and crime fiction not only proves his admiration for the English baronet but also shows Poe's simultaneous attempt to justify his own fiction through reviewing Bulwer-Lytton's works, thus ultimately identifying his feeling of grievance and injustice as a writer with that of the Victorian aristocrat, especially when the latter was harshly criticised for writing sensation novels of crime in Victorian England. In this respect, it could be argued Poe was willing to envision himself as Bulwer-Lytton's American literary double.

As a matter of fact, at the time when Poe was engaged in writing reviews of BulwerLytton's works, Charles Dickens, who was a close friend of Bulwer-Lytton's, began a tour across the United States in 1842 which would lead him to become acquainted with Edgar Allan Poe and maintain correspondence with him after his return to England. Likewise, even after Poe's death, when Dickens returned to the United States in 1851, he visited Maria Clemm, Poe's aunt and mother-in-law, and contributed to helping her financially, thus proving Poe had exerted a deep impression on Bulwer-Lytton's closest literary friend. In this respect, Charles Dickens could have well become a literary mediator between both writers across the Atlantic, as he discussed his novel Barnaby Rudge during his interview with Poe, as well as decided to change the end of Great Expectations following BulwerLytton's advice.

At that time, due to the lack of strict copyright laws, English writers like Edward Bulwer-Lytton were widely read on the other shore of the Atlantic, while Poe's fame was also progressively increasing in England and appeared to reach its peak after the publication of his poem "The Raven" in 1845. During the Victorian period, Edward Bulwer-Lytton became a highly esteemed man of letters in addition to a reputed Member of Parliament. Nonetheless, through the advent of Modernism, Bulwer-Lytton's fame gradually fell into oblivion, while Poe's reputation significantly arose, especially through the reception of his works and aesthetics in European countries such as France.

This comparative analysis between both authors is tackled within the field of transatlantic studies, which, according to Susan Manning and Andrew Taylor, draw attention to the ways in which ideas of crossing and connection have helped to rethink how national identity has been formulated (2007:4). Consequently, to use Paul Giles' words, transatlanticism reconsiders national formations from a position of estrangement, describing American literature from a comparative standpoint (2002:3). The focus on examples of intertextuality between Edgar Allan Poe and Edward Bulwer-Lytton may shed light on a significant literary link in Victorian times, underlining the ongoing relations between the newly independent nation, the United States, and its former metropolis, Great Britain, and how English and American authors envisioned the idea of influence and legacy across nations. In this respect, according to Robert Weisbuch, Anglo-American literary relations at that time usually brought to the 
floor the joys and sorrows of both British cultural stability and American instability, so that American writers often turned to England as the most relevant comparative model, only to find themselves in reluctant agreement (1995: xiii). In this respect, Edgar Allan Poe gave evidence of his admiration for the Victorian writer Edward Bulwer-Lytton, even though Poe's interest and style in literature increasingly differed from those of the Victorian man of letters in the course of his literary career.

As contemporary writers, Edward Bulwer-Lytton and Edgar Allan Poe published their early fictions when they both were in their mid-twenties. Bulwer-Lytton's first novella, Falkland (1827), and one of Poe's early tales, "The Assignation" (1832), present remarkable intertextual links around the illicit relationship of two lovers that eventually meet a tragic end as a result of their deed. Even if these two works were written when both authors were in their youth, they examine issues which will not only recur in succeeding works but also explore aspects specifically pertaining to their family background, thus proving the important role their origins played all through their early and subsequent works.

Bulwer-Lytton's novella presents a compilation of letters depicting the adulterous relationship between Erasmus Falkland and Lady Emily Mandeville, compiling Falkland's epistles addressed to Emily and his close friend Frederick Monkton, as well as Emily's letters to her husband Mr Mandeville and her lover Falkland. Likewise, Poe's tale "The Assignation" is set in Venice and unfolds how a stranger saves the Marchesa di Mentoni's child from drowning while her husband witnesses this event without intervening, thus implying he knows about the adulterous relationship that has been taking place between his wife and the stranger, and even inferring the child the Marchesa is embracing is not his own.

In addition to the tribute both writers paid to Lord Byron in their youth through the figure of the stranger in Poe's tale and the character of Falkland in Bulwer-Lytton's novella, these two early works also underline important biographical details in relation to both writers such as their early and lonely upbringing, the demise of an early love, their infatuation with a mature woman in their youth, issues with regard to legitimate inheritance and parentage, as well as illicit relationships and their ultimate consequences.

\section{BROUGHT UP IN ISOLATION: THE LONELINESS OF BULWER-LYTTON, POE AND THEIR HEROES}

After his biological mother's premature death, Edgar Allan Poe was adopted by the Allans when he was scarcely two years of age. Even though his foster mother, Frances Allan, was doting and caring, John Allan always remained a distant father, often quarrelling with Edgar as a result of his dissolute habits. Poe's aloofness when he was a child became particularly acute during his stay in Great Britain from 1815 to 1820 , when he was sent to different boarding schools in England, and later on, in Scotland. Likewise, Bulwer-Lytton was also the son of a doting mother, Barbara Lytton, and of a distant father, General Bulwer, who died when Bulwer-Lytton was merely four years old. Having been selected as heir of Knebworth House, Bulwer-Lytton was brought up by private tutors in the family manor before he was sent to school, thus leading an eminently lonely childhood, in constant application to his studies and detached from any peers of his own age. The lonely upbringing 
both writers experienced, which would ultimately lead them to become precocious children, bears a remarkable resemblance with that of the male protagonists in their early fictions.

In Bulwer-Lytton's epistolary novella, Erasmus Falkland confesses to his friend Frederick Monkton he takes delight in the isolated existence he leads on his own, detached from any social gaieties, relapsing into himself and acquiring the habit of deep reflection while, in his letters, Monkton provides Falkland with accurate depictions of the fashionable gatherings of the season, at which he is a common guest. Even if both friends used to be closely attached to each other, their different approaches to life - Monkton, fond of society and Falkland, keen on isolation - have gradually set them apart. After suffering the pain of his first love's demise and going back home after a period of time abroad, Falkland has just crossed the threshold into adulthood, and yet, his estrangement from the world and his perpetual seclusion in the manor house of his family have rendered him aged before due time.

Falkland spends his young adulthood in an ancient abode, "a ruin rather than a house" (11), refurbished with large bookcases, exotic decoration and a gloomy atmosphere. Nonetheless, his will to renounce any contact with the outside world as well as any social gaieties renders him an outcast, rejecting action and taking pleasure in reflection instead, thus undergoing a premature process of ageing. Falkland's mansion not only stands for his abode but it also acquires a special transcendence as it allows him to relapse into the past and indulge in reveries due to his thoughtful and visionary nature, describing himself as "Prospero in his desert island" (30). Falkland thus lives in a world of his own, indulging in reveries and dreams which detach him from reality and everyday existence.

In clear resemblance with Falkland's Byronic characterisation and the way Monkton portrays his friend's gloomy isolation and his indulgence in day-dreaming, the narrator in Poe's "The Assignation" - a tale which was precisely first entitled "The Visionary" - rejoices in the visualization of a mysterious and ill-fated man he beholds in the streets of Venice; a well-known popular romantic figure strongly reminiscent of Lord Byron. In retrospection, the narrator confesses he believes this vision to be a daydream as it is argued the man resides in "the cold valley and shadow" (116) after dying in the prime of his youth. Likewise, he also highlights the stranger's imagination and powers of meditation, arguing nobody should blame him for his visionary nature as the narrator himself acknowledges his belief in other worlds than in merely earthly existence. The narrator also refers to the stranger asserting he had "fallen in the flames of thine own youth" (116), thus highlighting that his passionate nature and his profligate manners eventually led him to death. The stranger's passionate existence and his ardent willing to live eventually cut his own life short, ensuing an untimely death and thus dying before due time. Consequently, Bulwer-Lytton's Falkland and the Byronic stranger in Poe's tale emerge as parallel figures, doomed and tormented despite their apparent youth, concealing a secret deed, in constant pursuit of knowledge, indulging in reveries and living a life of seclusion, detached from the rest of human beings, and ultimately growing old before due time.

\section{A FIRST RITE OF PASSAGE: THE DEMISE OF THE FIRST LOVE}

According to James Campbell, when Bulwer-Lytton had not even turned twenty years of age, he spent a period of time at Ealing, where he had a platonic love affair with a young girl 
that would exert an enormous influence on him both personally and professionally, giving rise to his "lifelong romantic idealism" (Campbell 3). Bulwer-Lytton and Lucy used to meet secretly along the banks of the river Brent until Lucy suddenly disappeared. Three years later, Bulwer-Lytton received a letter Lucy had written on her deathbed, explaining that her father had compelled her to marry a man she had never loved. This romantic disappointment threw Bulwer-Lytton in a permanent state of melancholy and depression.

Similarly, when Edgar Allan Poe was barely fifteen years old, he became infatuated with Jane Stith Stanard, mother of Robert Stanard, one of Poe's classmates in Richmond. Even though Jane died soon after Poe became in love with her, he would refer to her as "the first purely ideal love" of his soul and would consider her as his first Helen, as he would admit many years later in a letter he addressed to Sarah Helen Whitman when he was courting her in October 1848, scarcely one year before he died. As happened with Bulwer-Lytton's first love, Jane Stith Stanard died when Poe was only fifteen years of age, leaving him grief-stricken and providing him with a theme that would recur in all his fiction as is the death of a beautiful woman (Sova 227). The remembrance of a lost love at such an early age exerted a deep influence on both writers' creativity. Nonetheless, both writers also had to bear the death of a parent at a very early age. Poe's mother, Elizabeth Arnold, died when Poe was only two years old, after her husband, David Poe, had already abandoned the family. Likewise, Bulwer-Lytton's father, General Bulwer, died of gout when his son was scarcely four years old.

In Bulwer-Lytton's novella, Falkland confesses the death of his parents involved the first actual change which took place in his life, leaving him under the auspices of melancholy at a remarkably young age. His uncle, a Member of Parliament, became Falkland's guardian, sending his nephew to school where Falkland remained constantly surrounded by mischievous associates, feeling both fear and aversion towards the school principals. Falkland was then sent to a private tutor with whom he spent two years in order to be trained for Oxford, where Falkland was to spend three more years. Nonetheless, it is precisely before Falkland moved to Oxford that he felt "the first awakening of the most powerful of human passions" (18), which ended in despair when the first woman he had ever loved tragically died.

Even if Falkland is reluctant to dwell upon this tragic event of his youth, he acknowledges that, for an individual inclined to melancholy and seclusion, the death of the first woman he had ever loved compelled him to apply to study and the pursuit of wisdom earnestly, thus indulging in a life of seclusion, ignoring the present and devoting his entire existence to the knowledge of the past. However, his voluntary isolation and his intention to emulate Faustus only leads him to misery as he gains insight into the loneliness of his own existence, acknowledging the first symptoms of ageing, thus confessing:

All knowledge brings us disappointment, and this knowledge the most - the satiety of good, the suspicion of evil, the decay of our young dreams, the premature iciness of age, the reckless, aimless, joyless indifference which follows an overwrought and feverish excitation - These constitute the lot of men who have renounced hope in the acquisition of thought. (29) 
Falkland's first love's demise prompted his reluctance to take part in social gatherings and live at present, choosing instead to lead an alternative existence on his own. Falkland's seclusion in his family's manor house, the abode where he spent his childhood, quickens his own process of ageing, thus confessing, despite his young adulthood, he has acquired many habits pertaining to the old. Disappointed with any kind of earthly existence after suffering acute grief and melancholy, his manhood has granted him a meditative nature, dismissing a youth of passion in favour of the experience of the mind. It is at this stage that Falkland realises his existence bears a close resemblance with Charles Robert Maturin's character, Melmoth, thus confessing he "passed at once, like Melmoth, from youth to age" (20). Falkland often compares himself with both Melmoth and Faustus precisely in his constant pursuit of wisdom and his eagerness to abandon any youthful pleasures and indulge in a premature process of ageing.

\section{LOOKING BACK TO ENGLAND: ROOTED IN A BYRONIC MYTH}

According to Allan Conrad Christensen, Bulwer-Lytton's first novella, Falkland, reveals a "Bulwer Byronized" (27), mainly as a result of the effects of Byron's death at the time, together with Bulwer-Lytton's loss of his first love, Lucy, as well as the affair he had with Lady Caroline Lamb, Lord Byron's once sweetheart, his youth. Consequently, despite the explicit resemblance between Falkland and both Faustus and Melmoth, the hero of Bulwer-Lytton's first novel is strongly reminiscent of Lord Byron, particularly taking into consideration several features that characterise Falkland's life and fate, especially his excesses in youth, his passionate nature and romantic affairs, as well as his untimely death and his almost self-imposed exile at the end of his life. Bulwer-Lytton nourished a fervent admiration towards Byron in his youth, and even tried to adjust his own appearance so as to look like the English poet as closely as possible. Likewise, both Byron and BulwerLytton attended Trinity College, in Cambridge, and they both had a romantic relationship with the married Lady Caroline Lamb. Byron's relationship with Caroline Lamb caused an upheaval in the English society of the time, precisely because she was a married woman, as is the case with both Emily and the Marchesa di Mentoni in both Bulwer-Lytton's novel and Poe's tale, respectively. Despite the fact that Byron abandoned Caroline Lamb, she never entirely recovered and perpetually pursued him, contributing to circulating rumours about Byron's cruel and reprobate behaviour.

In clear analogy with Bulwer-Lytton, Poe also declared his early admiration for Byron's poetry and rebelliousness. As Dawn Sova argues, John Allan, Poe's assumed foster father, showed his hatred for the fashionable cult of the time around Byron and even blamed Poe's fondness of Byron for his protégée's profligate ways (2001: 41). In this respect, Poe often recited Byron in his lectures and, in clear resemblance with Bulwer-Lytton, the Byronic influence on Poe's works can also be perceived in Poe's manner of dress as well as that of the unnamed stranger in his tale "The Assignation".

In Poe's tale, the narrator feels puzzled when beholding the stranger's countenance as some of his traces send him back to classical times claiming, in relation to his features, that he had seen "none more classically regular, except, perhaps, the marble ones of Emperor Commodus" (120). Nonetheless, despite the stranger's insistence that he has never been to 
London, the narrator acknowledges his English origins, arguing that "the person of whom I speak was not only by birth, but in education, an Englishman" (126). The stranger's countenance and his manners are strongly reminiscent of those of Byron, especially taking into consideration that Poe's tale is set in Venice, where Byron spent an important period of his life. After separating from his wife and having a daughter, Byron abandoned England and started a tour across Europe. In 1816, he spent a period of time in Venice, where he had affairs with two married women, Marianna Segati and Margarita Cogni; the latter throwing herself into the Venetian canal when Byron deserted her, which is a scene strongly reminiscent of Poe's tale. Nonetheless, it was during 1818 and 1820 that Byron made the acquaintance of the young Contessa Teresa Guiccioli, whom Byron asked to elope with him. As a matter of fact, according to Dawn Sova, Poe's tale is an account of the affair which took place between the English poet Lord Byron and Countess Teresa Guiccioli, who, as is the case with the Marchesa di Mentoni in Poe's tale, was also married to an older Venetian nobleman. Consequently, not only does Poe's tale revolve around this plot, but BulwerLytton's first novel also seems to develop on the basis of these actual facts.

In terms of their physical appearance, there is also a close parallelism set between Falkland and the Byronic stranger in Poe's tale, especially with regard to their curly hair and their prominent forehead. At Lady Margaret's dinner, Falkland's features are highlighted, referring to

the melancholy depths of the calm and thoughtful eye, there sat a resolution and a power $[. .$.$] and his hair, of a light chestnut, fell in large antique curls over his forehead.$ That forehead, indeed, constituted the principal feature of his countenance. (37)

In clear analogy with Falkland, in Poe's tale, the narrator's encounter with the stranger in the streets of Venice prompts a description which closely resembles that of the hero in Bulwer-Lytton's novel: "[e]yes, whose shadows varied from pure hazel to intense and brilliant jet - and a profusion of curling, black hair, from which a forehead of unusual breadth gleamed forth at intervals all light and ivory" (120). Both descriptions focus on the characters' mournful eyes, their profuse curly hair, and their prominent forehead, which are clearly reminiscent of those of Byron, thus showing both Bulwer-Lytton's and Poe's tribute to the English bard.

\section{INITIATION INTO ADULTHOOD: THE MARRIED LADY'S EMBRACE}

When Bulwer-Lytton became infatuated with the socialite Lady Caroline Lamb in 1824, she was in her late thirties, while he was scarcely in his early twenties. Likewise, Poe's first acknowledged love, Jane Stith Stanard, being the mother of one of his schoolmates, was about sixteen years Poe's senior. In addition to this remarkable age difference, both ladies had been previously married and had children of their own, thus being significantly more experienced than their respective young suitors. Even though both Poe and Bulwer-Lytton felt heartbroken at the end of these relationships, the memories of these first infatuations were to remain all through their lives as they considered them to be their first rite of initiation into love. In addition to indulging in apparently illicit relationships, as both ladies had been 
previously married, the exchange of innocence and experience that took place between both lovers also subverted any standards of the so-called 'appropriate behaviour' according to ageing, as is also shown in both author's early fictions.

In this respect, in Bulwer-Lytton's novella, Falkland admits the yearning for affection he used to feel in his early youth vanished with the death of his first love. After suffering the grief of his lover's demise, the experience of years has taught him to consider the recollections of the past with suspicion and acknowledge the time to enjoy love has departed along with his early youth. Nonetheless, even if inadvertently, it is in his adulthood that Falkland will experience the acutest feelings of love gone wrong when he gets acquainted with Emily Mandeville; a woman married to a Member of Parliament and mother of a three-year-old child. Innocent and chaste, Emily got married at sixteen and had her child at eighteen, and despite being a wife and a mother, she retains the ingenuousness and inexperience of a child, thus illustrating the figure of the Victorian angel of the house. Despite her innate shyness, as a woman pertaining to the upper-classes, Emily often attends social gatherings, and it is there she first hears of her lover to be, as Falkland is often described as a character possessing every feature to please society such as youth, good manners, talent, and knowledge of the world as a result of his earnest study and his journeys abroad.

Even if Emily and Falkland are formally introduced when they are both invited to Lady Margaret's dinner, Emily had already been acquainted with Falkland when she took a walk in the countryside and found a man lying down sleeping beside a volume of Shakespeare's Midsummer Night's Dream, whom she would subsequently identify as Falkland. Emily's attention focuses on one of the passages the sleeper had been perusing, finding herself reciting 'the course of true love never did run smooth'; a line which will remain essential and foretelling for both lovers. When beholding Falkland's countenance once more at Lady Margaret's manor house, Emily immediately identifies the same person she had met lying by the lake and thus cannot help but blushing deeply when she replies to Falkland's salutation.

Thus, the resemblance between both male characters, Falkland and the stranger, can also be extended to the heroines of both texts. If Emily blushes when she is firstly introduced to Falkland, in Poe's tale the narrator also notices the Marchesa di Mentoni's shyness when the stranger approaches her after having rescued her child from death, wondering, out of perplexity, "[w]hy should that lady blush! To this demand there is no answer" (119).

Moreover, according to Falkland, Emily's countenance denotes both happiness and gloom, making use of the antithesis "too feeling to be gay, and too innocent to be sad" (39). In analogy with the Marchesa di Mentoni - aptly called Aphrodite in the 1845 version of Poe's tale - the narrator reflects on her beauty while beholding her portrait in the stranger's abode, also highlighting both mirth and melancholy in the Marchesa's face: "in the expression of the countenance, which was beaming all over with smiles, there still lurked [...] that fitful stain of melancholy which will ever found inseparable from the perfection of the beautiful" (126). Consequently, despite both heroines' radiance, they both betray an acute sensibility - or even melancholy - that renders them particularly vulnerable. Both being wives and mothers, they are no longer in their early youth but in the early womanhood, beginning to gain insight into their own existence becoming aware of their true feelings, and undergoing a process of ageing. 
In terms of ageing, Falkland's detached existence and his voluntary isolation in his family manor house have rendered him prematurely aged, while Emily has so far led a life devoid of grief and turmoil, devoted to her duty and accepting her assigned role as a Victorian wife and mother. Emily's high sense of duty and responsibility, as well as her innate innocence, prevents her from noticing the affection she is beginning to feel for Falkland. Nonetheless, Emily's countenance gradually suffers a perceptible change which reflects the transformation she is undergoing. By means of her growing attachment to Falkland, Emily also acquires some of his ways, his mournful and melancholy look as well as his nonchalance. Her slow but progressing insight into her own feelings adds guilt to her newly-acquired melancholic ways, which render her precociously aged despite being considerably young. Falkland also notices the transformation Emily gradually suffers as a result of their increasing attachment:

Since Falkland had known Emily, her character was much altered. Six weeks before the time I write of, and in playfulness and lightness of spirits she was almost a child: now those indications of an unawakened heart had mellowed into a tenderness full of melancholy. (63)

As opposed to Emily, whose guilty affection quickens her process of ageing, Falkland's usual moody ways are turned into happiness even if well-aware of the crucible that Emily is going through, for which he is the only one to be blamed, thus contending "I wander in the delirium of a fatal fever, in which I see dreams of a brighter life, but everyone of them only brings me nearer to death" (53). Through his infatuation with Emily, Falkland has regained the strength and vitality he has lacked for years in his so long pursued life-in-death enclosure, while Emily undergoes an ongoing process of ageing as happens to the painter's wife in Poe's well-known tale "The Oval Portrait".

\section{THE EMBODIMENT OF GUILT: THE ROLE OF THE CHILD}

In Bulwer-Lytton's novella, as a result of their guilty attachment since Emily is a married woman, the passionate relationship uniting both lovers seems to be cursed from its beginning since, in addition to her decaying health, Emily also admits that her dear son no longer absorbs all her thoughts but it is Falkland who now mostly attracts her attention. Her countenance has suffered so great a change that Emily feels worried when her husband, $\mathrm{Mr}$ Mandeville, informs her about his forthcoming arrival, as she feels certain he will enquire after her paleness and the alteration she has lately gone through. In contrast, in a letter to Emily, Falkland admits he has gained strength and eagerness, confessing she is the only one to account for his new vitality and rejuvenation, thus saying: "[i]t is you, who, when I was most weary of existence, gifted me with a new life. You breathed into me a part of your own spirit; my soul feels that influence, and becomes more sacred" (70). Falkland's renewed vivacity has been gained as a result of Emily's gradual decay in health, which in turn echoes the heroine's progressive fall into sin and guilt. Emily's gradual detachment from her son, even when she still loves him dearly, unleashes her progressive moral decline which will ultimately entail her irrevocable fall. 
The first encounter between Falkland and Emily takes place during an excursion to a cavernous region in the countryside, which already foretells a tragic closure. When the tide rises, Emily feels trapped and Falkland has to rescue her from drowning. This episode in Bulwer-Lytton's novel is strongly reminiscent of the passage in Poe's tale whereby the stranger saves the Marchesa's child after she accidentally drops him into the canal. In both cases, these dramatic episodes echo both heroines' irretrievable fall from innocence. Once Falkland saves Emily from drowning in the sea after the water had covered the path, they both join each other in a passionate embrace; an epiphanic moment which will reverberate all through their illicit liaison. Even if Emily had lately felt enfeebled as a result of her inner guilt, it is in the course of this embrace she awakens into passion, thus precluding her fall from innocence and her christening into real existence. Falkland gains insight into Emily's change when she turns and he realises "her cheek was no longer pale" (66). In Poe's tale, once the Marchesa's child is also saved from drowning and the stranger approaches her holding her child, the narrator realises she also undergoes a transformation, from marble to crimson, transforming her pallor pertaining to a goddess statue into the blushing countenance of a flesh-and-bone woman, thus remarking "the statue has started into life! The pallor of the marble countenance, the swelling of the marble bosom, the very purity of the marble feet, we behold suddenly flushed over with a tide of ungovernable crimson" (119). For both Emily and the Marchesa, their illicit infatuation involves their coming into life, their first real encounter with real love, even if their actions also echo their eventual demise, as if the fall into the waters of the canal reverberated and anticipated their premature death.

This encounter will prove particularly fatal to Emily as, even though she acknowledges passion for the first time, her health worsens, ageing prematurely as a result of her guilt, while Falkland gains strength and vivacity due to his attachment to Emily, renouncing his seclusion and returning to early visions of love and youth. The Marchesa di Mentoni, often compared with the goddess Aphrodite because of her beauty, seems to gain life once the stranger touches her hand and gives her back her child, thus undergoing a transformation from goddess into a mortal being. In Poe's tale, it is precisely the Marchesa's child who is rescued from the canal, thus unveiling he might be an illicit child, and therefore the actual proof the Marchesa has had an adulterons relationship with the stranger.

The illegitimate relationship joining the lovers in each of the texts is also strongly reminiscent of both writers' situation in relation to their own background and parentage. In spite of the fact Poe was adopted by the Allans, he never became their legitimate heir. Moreover, scarcely one year after Frances Allan's death, John Allan married his second wife, Louisa Gabrielle Patterson, eventually having three legitimate sons of his own and thus depriving Poe of any possibility of a prospective inheritance. Having grown accustomed to a reasonably high standard of living since childhood, Poe's desperate need to gain access into certain social circles would become compulsive and would strongly contribute to his everlasting sense of frustration. He was well aware of his precarious situation and the importance attached to the right of legitimacy he claimed. Likewise, Poe was surely haunted by the fact his biological father had deserted both his wife as well as his children when they were all very young. According to Peter Ackroyd, one of the reasons for this abandonment was due to "the persistent gossip that Rosalie [Poe's younger sister] was not his child" (11). 
As a result of these personal experiences, the claim to assert or question his legitimacy as heir to the Allans remained an obsessive concern for Poe all through his life.

The obsession with legitimacy and inheritance was also particularly prevalent in aristocratic families like the Lyttons. Well-aware he would eventually inherit his noble title as a baronet, Bulwer-Lytton was well-acquainted with the importance attached to legitimacy and the right to inherit the family estates and properties since his early childhood. Despite the fact Bulwer-Lytton was the youngest of three siblings, his mother Barbara chose him as the legitimate heir to her manor, Knebworth House, even though Bulwer-Lytton himself admitted that this choice was probably offensive to his father (1883: 78), being an eldest son himself and very aware of the law of primogeniture. Moreover, even though Barbara eventually married General Bulwer, she had had several suitors before her marriage took place, but decided to reject them for the sake of what she perceived to be her duty as an English aristocrat. Nonetheless, when she was already married to General Bulwer, she was also courted by the brother of her old lover, Milnes Lowndes, who persisted in sending her copious letters in an attempt to indulge in some sort of platonic love. Even if this affair never came to any feasible end, in his autobiography, Bulwer-Lytton himself admitted his mother decided to keep it secret and never informed General Bulwer about the interest Tom Lowndes had begun to show for her at the time. Thus, both authors were well aware of the importance attached to legitimacy as prospective heirs as well as of the stigmatisation that illicit relationships may entail for the individual.

\section{THE OUTCOME OF A LOVE TRIANGLE: DUTY AND REBELLION}

Both Elizabeth Arnold, Poe's mother, and Barbara Lytton, Bulwer-Lytton's mother, might have surrendered to an illicit relationship, and this is portrayed in both author's early fictions. Similarly, even after he got married to Virginia, Poe is believed to continue visiting Jane Stanard's grave, unable to forget his first love (Silverman 126), and once Bulwer-Lytton was married to Rosina Wheeler, according to Marie Mulvey-Roberts, they mutually accused each other of maintaining illicit relationships with lovers. Likewise, in both Falkland and "The Assignation", both heroines' surrender to an illicit relationship is presented in a remarkably similar way in a passage which proves pivotal for the outcome of these two works. In this respect, despite her initial reluctance, Emily finally decides to give herself to Falkland, thus confessing: "Oh Falkland! You have conquered! I am yours - yours only [...] I could restrain myself no longer; all my virtue, my pride, forsook me at once. Yes, yes, you are indeed my world. I will fly with you anywhere - everywhere" (116). In clear analogy with this episode, in Poe's tale, the Marchesa di Mentoni also succumbs to the stranger, as the narrator unveils her words thus confessing " 'Thou hast conquered' - she said, or the murmurs of the water deceived me - 'thou hast conquered - one hour after sunrise - we shall meet - so let it be!'” (119-20). These two passages from Bulwer-Lytton's novel and Poe's short-story prove similar enough so as to underline the intertextuality existing between both texts, describing both heroines' fall from grace and irremediable downfall as a result of their decision to succumb to illegitimate passion.

Nonetheless, if in Bulwer-Lytton's novel both Falkland and Emily arrange a meeting beside the lake, where they embrace again, despite their announced assignation, the Marchesa 
and the stranger never see each other again. The lovers' meeting beside the sea, a canal or a lake recurs in both texts, thus underlining the double-edged nature of their illicit liaison, symbolised by the reflection in the waters and their reverberation, which subverts social and moral standards as well as the expected course of ageing. These effects are particularly noticeable in terms of the heroines' appearance and the heroes' behaviour. Despite Emily's youth, her guilt quickens her process of ageing, while Falkland resumes his youthful period growing detached from his permanent isolation. Similarly, the Marchesa di Mentoni gains life, and thus mortality, as the narrator beholds her metaphorical transformation from a goddess to a human being. Her attainment of human qualities also renders her a mortal being, thus subjected to the process of ageing. Likewise, Emily's transformation becomes a fact when Falkland has some disturbing dreams about his lover whereby he witnesses her quick transition from youth to age in this manner:

He saw, as through a floating and mistlike veil, the features of Emily; but how changed! - sunken and hueless, and set in death. The dropping lip, from which there seemed to trickle a deep red stain like blood; the leadlike and lifeless eye; the calm, awful, mysterious repose which broods over the aspect of the dead. (123)

Falkland has this vision after his illicit encounter with Emily, which foretells Emily's forthcoming death.

In Poe's tale, when the stranger goes back to his apartment after his encounter with the Marchesa on the Bridge of Sighs, he beholds a portrait of Mentoni's wife, whereby the stranger's guest, the narrator, observes the Marchesa's goddess-like countenance, but also the way some melancholy lurks underneath her deliberate smile. Gradually both heroines undergo a transformation which anticipates their eventual death. If the Marchesa's candid countenance acquires a melancholic expression as the narrator beholds her portrait in the stranger's apartment, Emily's health gradually decays to the extent she breaks a blood-vessel as a result of the pressure she is compelled to bear. If the Marchesa's countenance betrays some nostalgia, it is Emily's expression and health which mostly show her unfathomable guilt. Emily often feels the invigilating eye of her husband, even though, her behaviour is mostly reprimanded by her own conscience and her high moral standards. Eventually, it is precisely Emily's husband who accuses his wife of adultery, giving her back one of the letters she addressed to her lover. As a result of her husband's forceful reproach, Emily dies, and Falkland is able to behold the transformation her countenance suffers as a result, resembling the nightmarish vision Falkland had of his lover last night, "the changed and lifeless countenance of Emily Mandeville" (126). If Emily's behaviour is reprobated by her husband, the encounter between the Marchesa and the stranger on the Venetian Bridge of Sighs is also witnessed by the reproachful husband Mentoni, who seems totally unconcerned about the recovery of his child.

Following Emily's death, Falkland also suffers a transformation, as his renewed grasp to life comes to a close, falling senseless on the precise spot where his encounter with Emily had taken place the previous night. As a result of this tragic experience, given his Spanish origins, Falkland decides to accept his uncle's proposal to join him and return to Spain to fight by the side of General Riego, thus complying with his mother's wish to fight for her country. Nonetheless, Falkland's acceptance originates as a result of his wish for 
forgetfulness and excitement, rather than out of any enthusiasm to fight for the Spanish cause. In the context of the Napoleonic Wars, the Spanish War of Independence, which lasted from 1808 to 1814, following the fight between France, and the United Kingdom as well as Portugal, unleashed as a result of Napoleon's wish to announce his monarchic ideals and proclaim his brother as the monarch of Spain to the detriment of the Borbonic heir. Falkland's decision to take part in this battle is reminiscent of Lord Byron's concern about the Greek independence from the Ottoman Empire, taking part in the rebel army despite his lack of military experience.

Nevertheless, neither Falkland nor Lord Byron die in the battlefield. Falkland is seriously injured in battle, and even if medical aid is procured, his recovery is deemed hopeless. In clear analogy with Emily's death, Falkland expires at the same hour she passed away, half an hour after midnight, thus unveiling the insurmountable bond which joined both lovers until the end. Significantly enough, Falkland expires holding an open locket of dark hair and pressing it convulsively upon his chest, thus recollecting Emily and holding on to the memories of his departed lover.

Similarly, in Poe's tale, while the narrator is attentively listening to the stranger's soliloquy about the realm of dreams that awaits him, a page from Mentoni's household announces the death of the Marchesa di Mentoni as a result of poisoning. Likewise, when the narrator approaches the stranger he finds him lying inert, adverting that the goblet from which he had been drinking contained a poisonous solution. By means of an end reminiscent of Shakespeare's Romeo and Juliet, the narrator gains insight into the actual nature of both lovers' assignation, having arranged to commit suicide and meet in the afterlife. If Falkland wondered whether there was anything as life after death or rather eternal silence, the stranger rests assured there exists "a land of real dreams whither I am rapidly departing" (127). The stranger thus betrays the world of dreams is more real for him than earthly existence as it is in this afterlife both lovers may remain together.

Even though in both texts the lovers find their death precisely owing to their illicit relationship, in Bulwer-Lytton's novel it is implied that Emily's death is the result of her fall and her sense of guilt, while Falkland's demise in battle also seems a matter of poetic justice. In contrast, in Poe's tale both lovers arrange a communal suicide by means of which they willingly decide to take their own lives. Thus, if guilt remains a core component in Bulwer-Lytton's novel and the characters are punished as a result of their illicit behaviour, in Poe's tale both lovers are left to do their wish, even if ultimately meeting the same end as Falkland and Emily.

\section{CONCLUSIONS}

An analysis of both authors' early fictions underlines significant intertextual links as well as brings to the floor biographical issues that will reverberate in their subsequent works as significantly important in their personal process of ageing. Through a Byronic myth that is reminiscent of his parental background as well as the demise of his first love, Poe gained insight into the impossibility of bringing back the irretrievable. The unfeasibility of recovering what has been tragically lost ultimately rendered him unable to fit in society; only being able to resort to rebelliousness and social ostracism. As opposed to this, even 
though Bulwer-Lytton also faced similar circumstances, such as the demise of his first love and the knowledge that a suitor may have menaced to disrupt his parents' union, he learnt very early from his mother that his duty as a noble man took precedence over everything else. Like Poe, he was also well aware of the importance of fate and determinism in one's life, but unlike Poe, he gladly accepted the responsibility of acting according to the social conventions attached to a man of his position.

In this respect, both authors' differing approaches in their early prose fiction, despite the remarkable parallelisms established between both stories, will reverberate in subsequent works. Bulwer-Lytton's high sense of morality envisioned as one of the main aims he attaches to fiction is underlined in his first novella, while Poe's aesthetics of 'art for art's sake' and the preference of art to the detriment of reality, thus fulfilling the artist's will, plays a major role in this early tale. In relation to ageing, Bulwer-Lytton's morality and consequent guilt would lead him to approach life and ageing bearing in mind public and social moral considerations, thus developing a high sense of individual responsibility which would revert to the Victorian society of the time. In contrast, Poe's approach to art and his preference for idealism interprets the experience of ageing as the struggle between the individual and the surrounding social standards, ultimately gaining insight into his impossibility to fit in society after having been detached from the circles he imbibed in his youth, thus being condemned to the torment of perpetual and nostalgic remembrance of the past. In this respect, in Poe's tale, even if both lovers decide to take their own lives, their behaviour is never questioned, as is envisioned within an imaginary realm, where only the narrator is left to tell the story.

In contrast, soon after its publication, Bulwer-Lytton decided to withdraw Falkland from the publishing market due to the contemporary reviews that pointed at its presumed lack of morality and its unchristian closure. Nonetheless, even if he agreed to ban its publication, Bulwer-Lytton defended the function of his fiction as a specially attuned domain to spread morality and edification, even if acknowledging the problematic issue of narcissistic contemplation and individual reflections disregarding society and its concerns.

All in all, the early fictions of Edward Bulwer-Lytton and Edgar Allan Poe paved the ground for a subsequent series of works that would present significant intertextual links. Even if Bulwer-Lytton became the heir of Knebworth House and was born in an aristocratic family, he also had to bear the social misinterpretation of his sensation novels under moral grounds. Likewise, Poe had to undergo the betrayal of his own foster family. After being brought up and accustomed to socialise in reasonably highly social circles, Poe was disinherited in his young adulthood, thus being unable to fit as a Southern gentleman in the American society from which he had been removed during his childhood. In this respect, Bulwer-Lytton had to age fast due to the responsibilities he had to acquire as heir, as he was inculcated commitment since his early childhood. In contrast, Poe's dissolute habits were rooted in an accommodated youth and in his inability to grow detached from the social ways he had acquired with the Allans after his ultimate quarrel with his foster father had taken place.

Even if both were required to age fast due to different circumstances, Bulwer-Lytton had a lifetime to bear his social responsibilities, since, as a result of fate, his future was predestined from the moment of his birth. In Poe's case, also as a result of fate, his adoption 
and acceptance into the Allans household gave him the comfort that otherwise he would have never known. Nonetheless, his estrangement from John Allan ultimately forced him to face an existence of his own; deprived of the comforts he had known during his youth. BulwerLytton's preference for duty and reality thus contrasted with Poe's fondness of rebellion and idealism as a result of the reversal of fortune. Nonetheless, their respective biographical details as well as the blatant intertextuality established in their fictional works can easily lead to perceive both authors as eminently nineteenth-century transatlantic doubles.

\section{REFERENCES}

Ackroyd, P. 2008. Poe: A Life Cut Short. London: Chatto and Windus.

Bulwer-Lytton, E.G. 2004. Falkland. Doylestown: Wildside Press.

Bulwer-Lytton, R. 1883. The Life, Letters and Literary Remains of Edward Bulwer, Lord Lytton by His Son. London: Kegan Paul.

CAmpBell, J.L. 1986. Edward Bulwer-Lytton. Boston: Twayne.

Christensen, A.C. 1976. Edward Bulwer-Lytton: The Fiction of New Regions. Athens: The University of Georgia Press.

Giles, P. 2002. Virtual Americas: Transnational Fictions and the Transatlantic Imaginary. Durham and London: Duke University Press.

Griswold, R.W. 1970. "The 'Ludwig' Article." The Recognition of Edgar Allan Poe: Selected Criticism since 1829. Ed. E.W. Carlson. Michigan: The University of Michigan Press. 28-35.

Manning, S. And A. TAylor, eds. 2007. Transatlantic Literary Studies: A Reader. Baltimore: The Johns Hopkins University Press.

Mulvey-Roberts, M. 2004. "Writing for Revenge: The Battle of the Books of Edward and Rosina Bulwer-Lytton." The Subverting Vision of Bulwer-Lytton: Bicentenary Reflections. Ed. A.C.Christensen. Newark: University of Delaware Press. 159173.

Poe, E.A. 1841. "Review of The Critical and Miscellaneous Writings of Sir Edward Bulwer-Lytton." Graham's Magazine. The E.A.Poe Society of Baltimore. Last Update: June 19, 1999. http://eapoe.org/works/ criticsm/gm41be02.htm

1848. "Edgar Allan Poe to Sarah Helen Whitman." Poe's Letters. The E.A.Poe Society of Baltimore. Last Update: December 18, 2009. http:/eapoe.org/works/ letters/p4810010.htm

2004. "The Assignation." The Selected Writings of Edgar Allan Poe. Ed. G.R.Thompson. New York and London: Norton. 116-128.

Silverman, K. 1992. Edgar A. Poe: Mournful and Never-Ending Remembrance. New York: Harper Perennial.

Sova, D.B. 2001. Edgar Allan Poe A to Z: The Essential Reference to His Life and Work. New York: Facts on File.

Weisbuch, R. 1995. Atlantic Double-Cross: American Literature and British Influence in the Age of Emerson. Chicago and London: The University of Chicago Press. 